\title{
Paraganglioneuroma of the duodenum: an evolutionary hybrid?
}

\author{
T. COONEY AND E. C. SWEENEY
}

From the Department of Histopathology and Morbid Anatomy, School of Pathology, Trinity College, Dublin, Eire

SUMMARY On light microscopy the neural component of a hybrid neural and endocrine duodenal tumour was characterised by ganglion cells and the endocrine component by epithelioid cells which were both argentaffin and argyrophil. Spindle-shaped cells of indeterminate lineage were also present. Electron microscopy revealed 'pale' and 'dark' cells, the former corresponding to the epithelioid cells and containing many membrane-bound neurosecretory granules, the latter probably corresponding to the spindle cells and containing large numbers of neurofilaments. Occasional cells contained both neurofilaments and secretory granules arranged in a consistent pattern in the cytoplasm. These composite cells may have represented an incompletely differentiated precursor of both the neural and endocrine elements of the tumour.

Eighteen cases of hybrid duodenal tumours containing ganglionic and paraganglionic elements have been described (Dahl et al., 1957; Friesen et al., 1974; Kepes and Zacharias, 1971; Kermarec et al., 1976; Lauzon and Cadotte, 1972; Lukash et al., 1966; Qizilbash, 1973; Taylor and Helwig, 1962; Weitzner, 1970). Two ganglioneuromas of the duodenum have also been reported and a relationship to the hybrid tumour suggested (Gemer and Feuchtwanger, 1966; Goldman, 1968). On light microscopy the tumour exhibits features of both ganglioneuroma and paraganglioma and is composed of diffusely scattered ganglion cells, small solid areas of spindle cells, and epithelial cell aggregates (Zellballen) with peripherally disposed vascular channels. The relative proportion of cell types in each tumour varies but the constitution of the entity is constant. In three of the cases described to date electron microscopy has revealed the presence of 'light' and 'dark' cells, membrane-bound secretory granules of catecholamine type, and fibrils consistent with neurofilaments (Kepes and Zacharias, 1971; Kermarec et al., 1976; Qizilbash, 1973). However, the disposition of secretory granules and neurofilaments within these tumours remains unclear. We report the light and electron microscopic features of a duodenal paraganglioneuroma in an effort to clarify the ultrastructural features of the various cell types and to suggest a possible histogenesis of the tumour.

Received for publication 17 August 1977

\section{Case report}

A 65-year-old woman with severe calcific aortic stenosis died in congestive cardiac failure. At necropsy a submucosal mass $1.0 \mathrm{~cm}$ in diameter was found on the posterior wall of the second part of the duodenum. The overlying mucosa was intact (Fig. 1a). Bisection of the mass revealed an oval tumour in the submucosa, the cut surface of which had a mottled light brown, haemorrhagic appearance (Fig. 1b).

\section{LIGHT MICROSCOPY}

The tumour was circumscribed but unencapsulated and was distinctly demarcated from the duodenal mucosa. Most of it was composed of rounded nests of epithelioid cells surrounded by a delicate network of reticulin fibres and ramifying capillary channels (Fig. 2). The epithelioid cells were exemplified by a large polyhedral cell with a round to oval nucleus which had a smooth nuclear membrane, peripherally condensed chromatin, and a prominent nucleolus. The cytoplasm of the cell was typically plentiful, eosinophilic, and finely granular. Variations in the plane of section resulted in some of the epithelioid Zellballen appearing as regular stacks of elongated cells, as noted previously by Taylor and Helwig (1962) (Fig. 3). Small solid areas of spindle cells with oval nuclei and tapered pale-pink cytoplasm were present, and scattered throughout the tumour were numerous definitive ganglion cells 


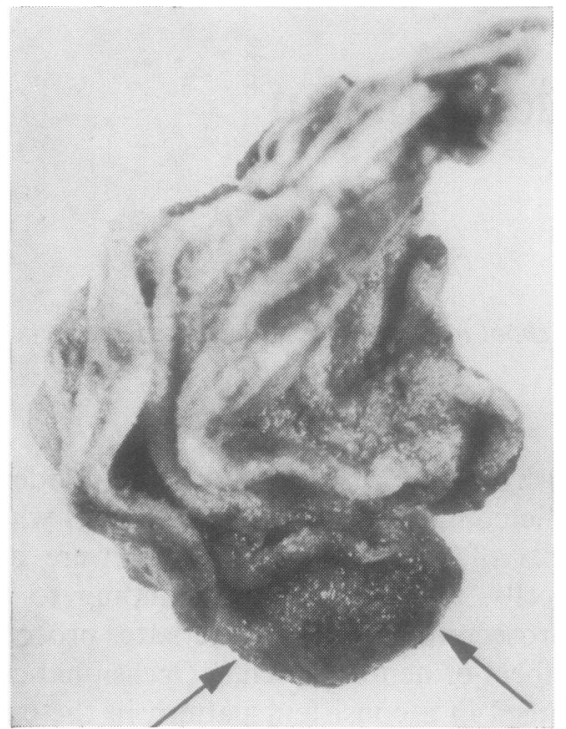

(a)

Fig. 1 (a) Pedunculated duodenal nodule (arrowed) showing intact overlying mucosa. (b) Cut surface of nodule with variegated pale, tan, and haemorrhagic areas. (Actual size $\times 2.5$ )

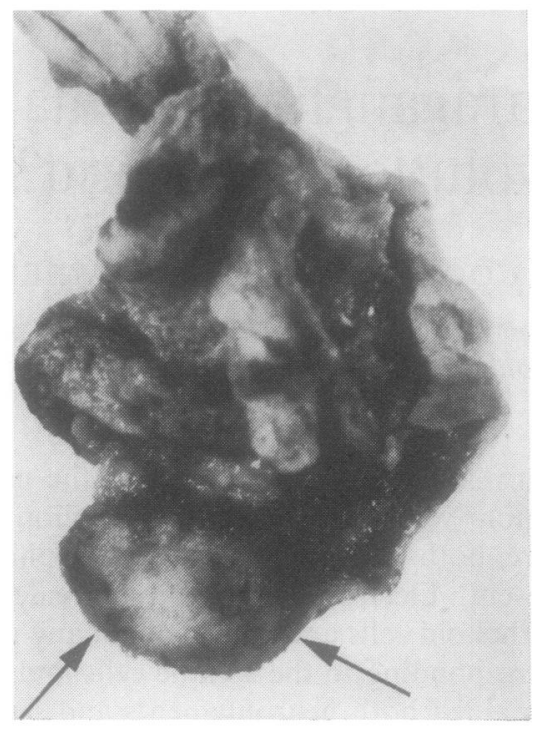

(b)

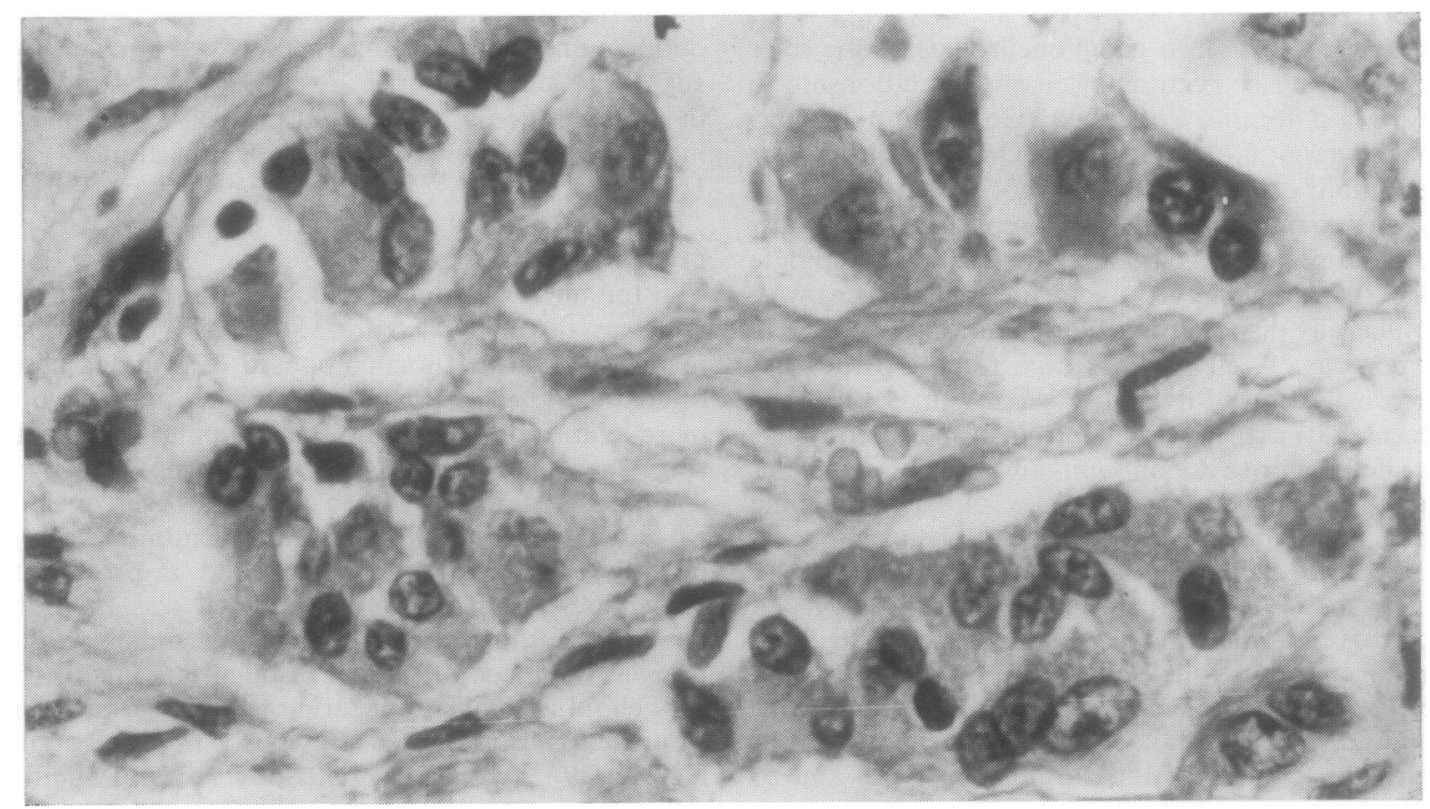

Fig. 2 Epithelioid cell nests with delicate supporting stroma, resembling Zellballen of carotid body tumour. (Haematoxylin and eosin $\times 400$ ) 


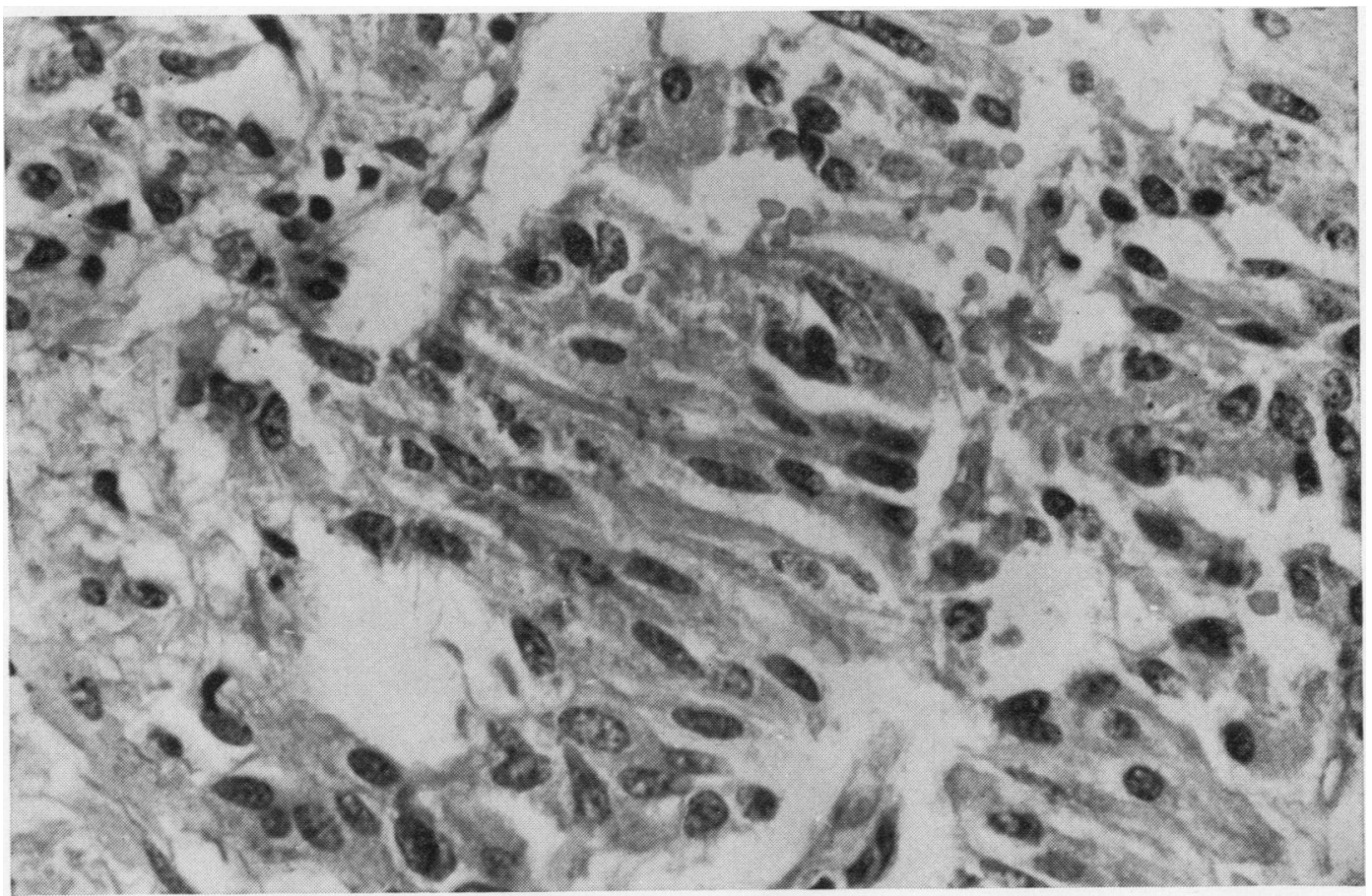

Fig. 3 Lamellar arrangement of epithelioid cells within Zellballen in some areas of the tumour. (Haematoxylin and eosin $\times 250$ )

(Fig. 4). The ganglion cells did not appear to bear any constant geographic relationship to the epithelioid cell nests, and although the majority were found between groups of epithelioid cells some were apparently within the Zellballen. In addition to the ganglion cells other neurites were also identified by the Bodian argyrophil stain that had oval vesicular nuclei, prominent nucleoli, and long tail-like processes (Fig. 5). Nissl substance could not be identified in any of the cells by the use of Luxol fast blue/ cresyl violet stain. The Bodian stain also revealed large numbers of nerve filaments in the stroma between epithelioid cell nests terminating in bulbous or clublike masses (Fig. 5). At one edge of the tumour a large nerve trunk accompanied by an artery and smaller vessels were identified penetrating the mass. Step sections of the tissue showed progressive branching of the nerve and vessels with smaller twigs petering out in the fibrovascular stroma between the Zellballen. Masson-Fontana stain revealed large numbers of coarse granules within the cytoplasm in a few of the epithelioid cells. More of these cells, including the argentaffin ones, exhibited finer argyrophilic granules using the modified Bodian technique. Argyrophil granules were also present in some of the ganglion cells.

\section{ELECTRON MICROSCOPY}

The tissue had been fixed in $10 \%$ formol saline. Small blocks were washed in veronal acetate buffer postfixed in $0.1 \%$ osmium tetroxide, dehydrated through graded ethanol, and embedded in epon. Sections were cut on an LKB ultramicrotome, stained with uranyl acetate/lead citrate, and examined with a Hitachi HU 12 electron microscope.

The principal feature seen on low-power scanning of the sections was the presence of lightly and darkly stained cells (Figs. 6, 7). The 'pale' cell corresponded to the epithelioid cell of light microscopy and contained large numbers of secretory granules within the cytoplasm. The 'dark' cell appeared to correspond to the spindle-shaped cells of light microscopy and contained numerous fine fibrils resembling neurofilaments, disposed parallel to the long axis of the cell (Fig. 8). Extracellular neurofilaments were not identified. Occasional cells contained both neurofilaments and secretory granules in a regular and characteristic array with a central core of filaments and a peripherally disposed mantle of granules (Fig. 9). In the perikaryon of the ganglion cells neurofilaments and secretory granules were also identified.

The neurosecretory granules described in the three 

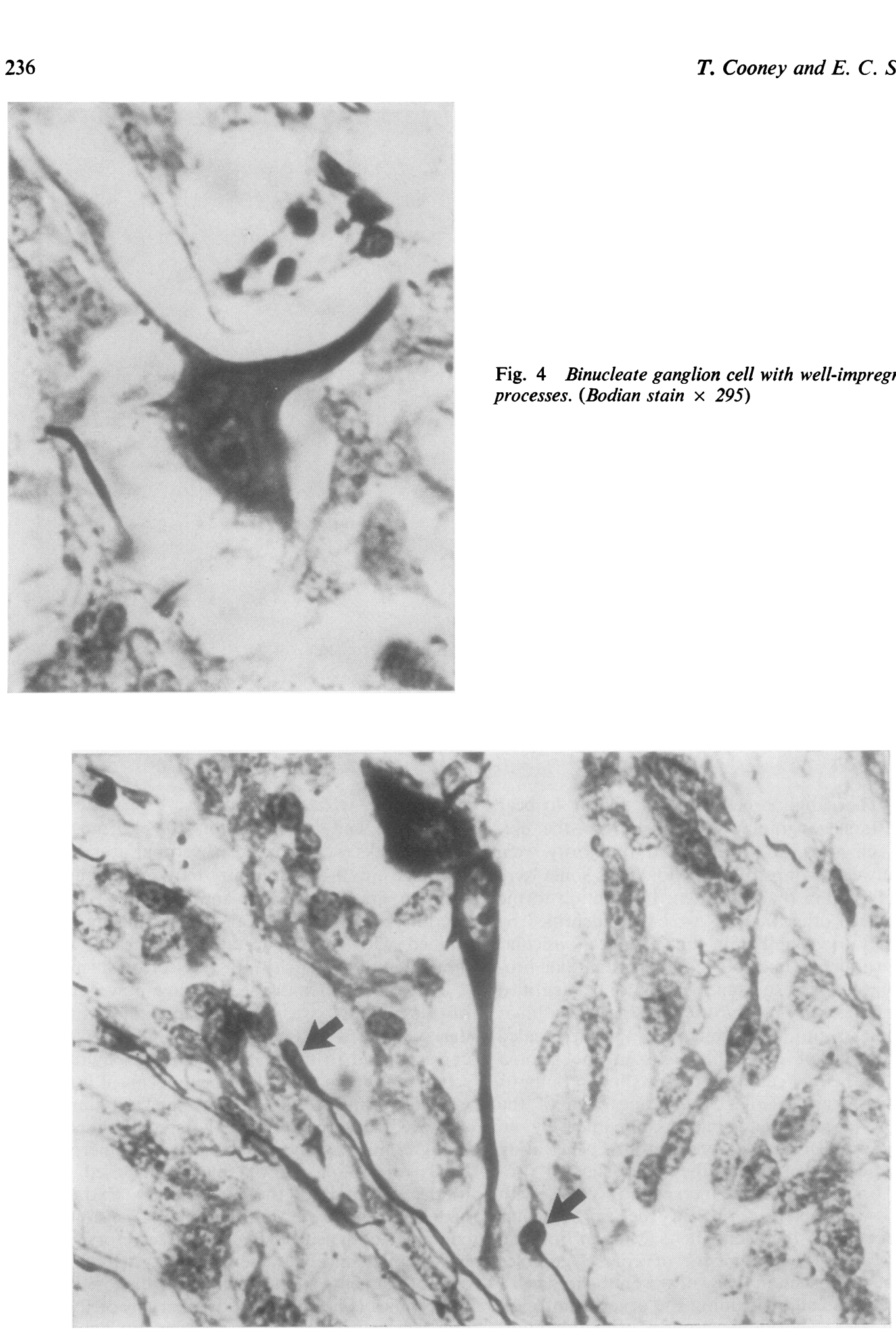

Fig. 5 Ganglion-like cell with long, well-impregnated tail. Note also nerve filaments with terminal bulbs (arrowed). (Bodian stain $\times 215$ ) 


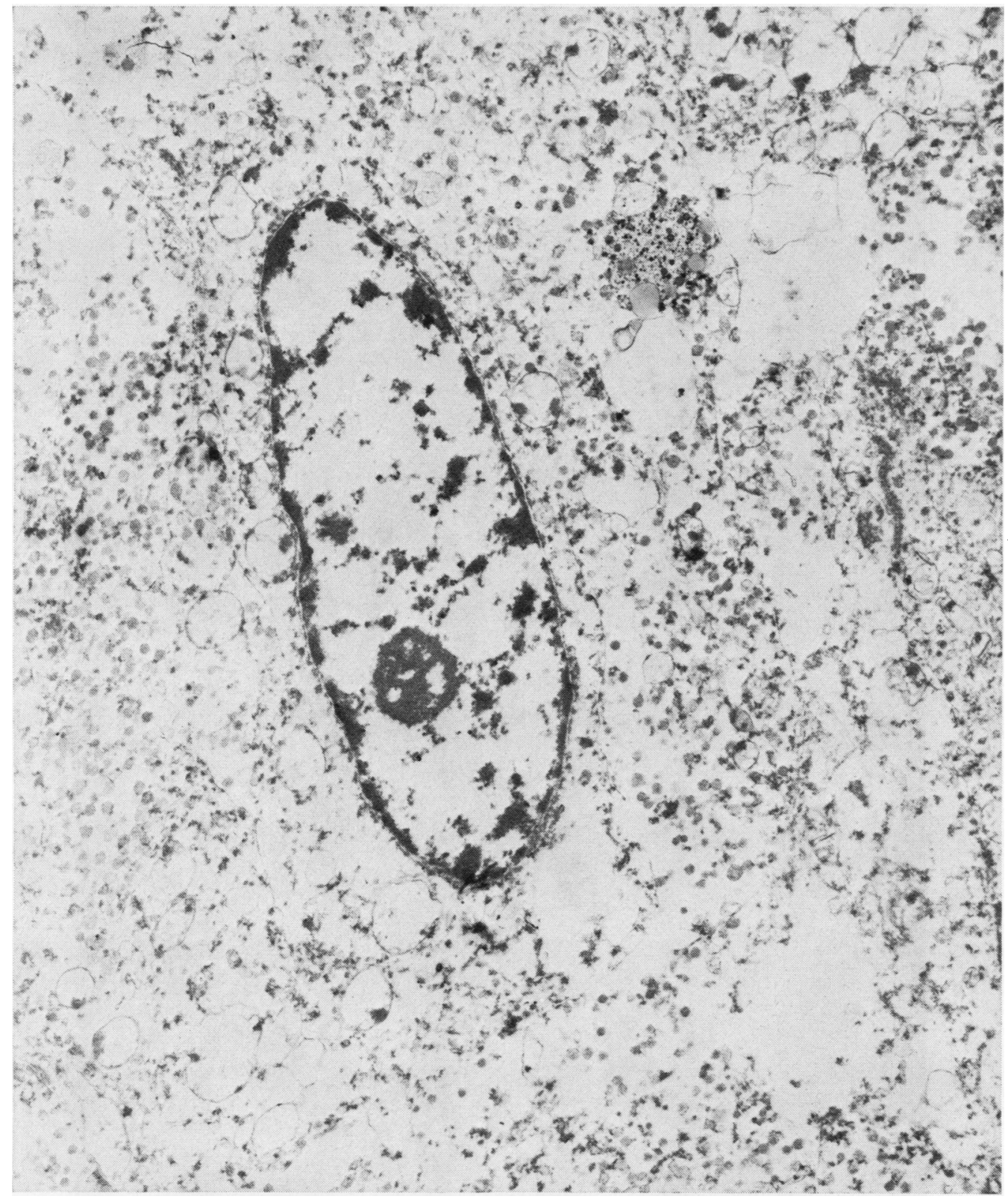

Fig. 6 Electron microscopic view of 'light' cell with multiple cytoplasmic granules. ( $\times 9000)$ 


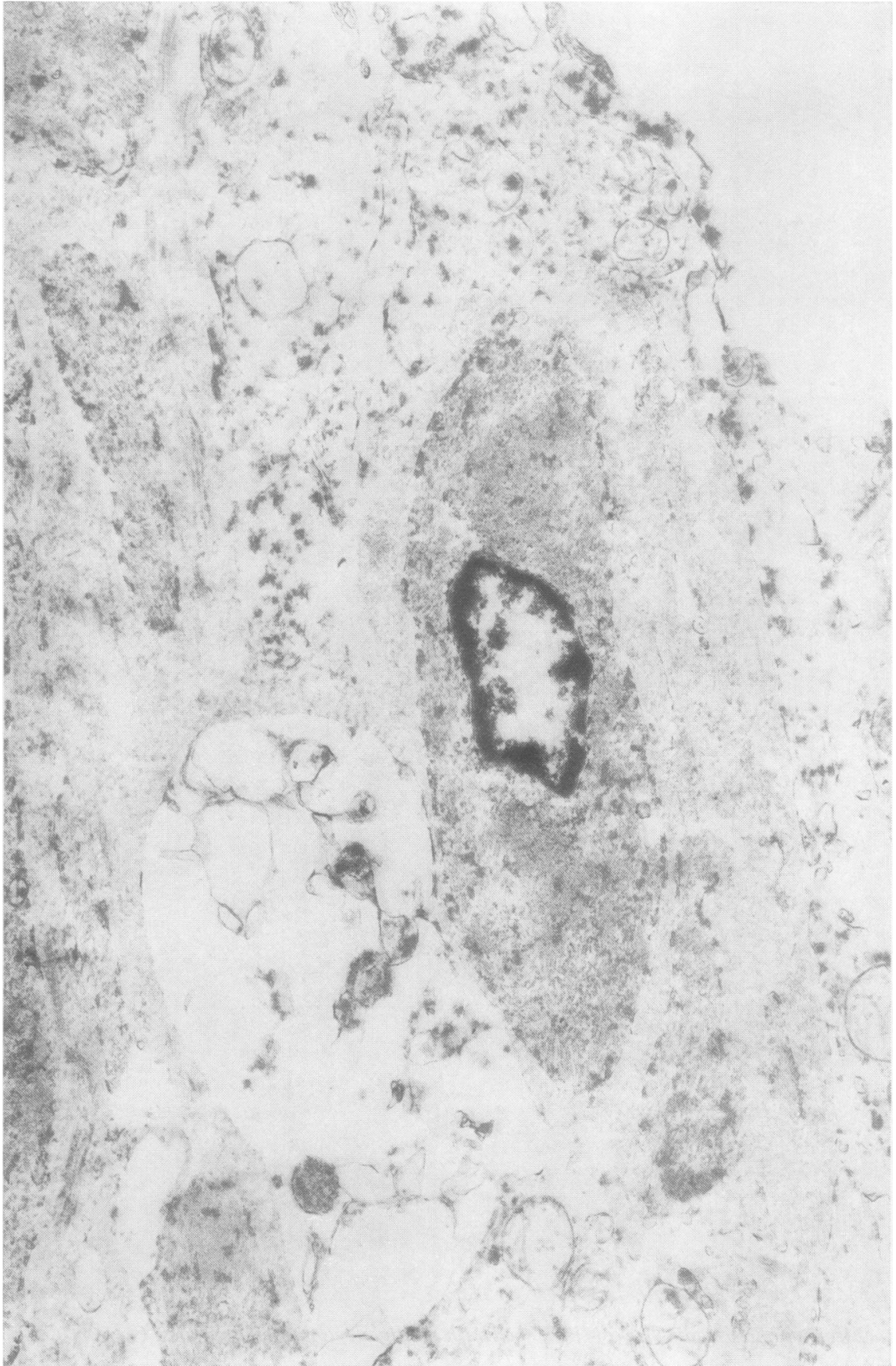

Fig. 7 Electron microscopic view of 'dark' cell. $(\times 14800)$ 


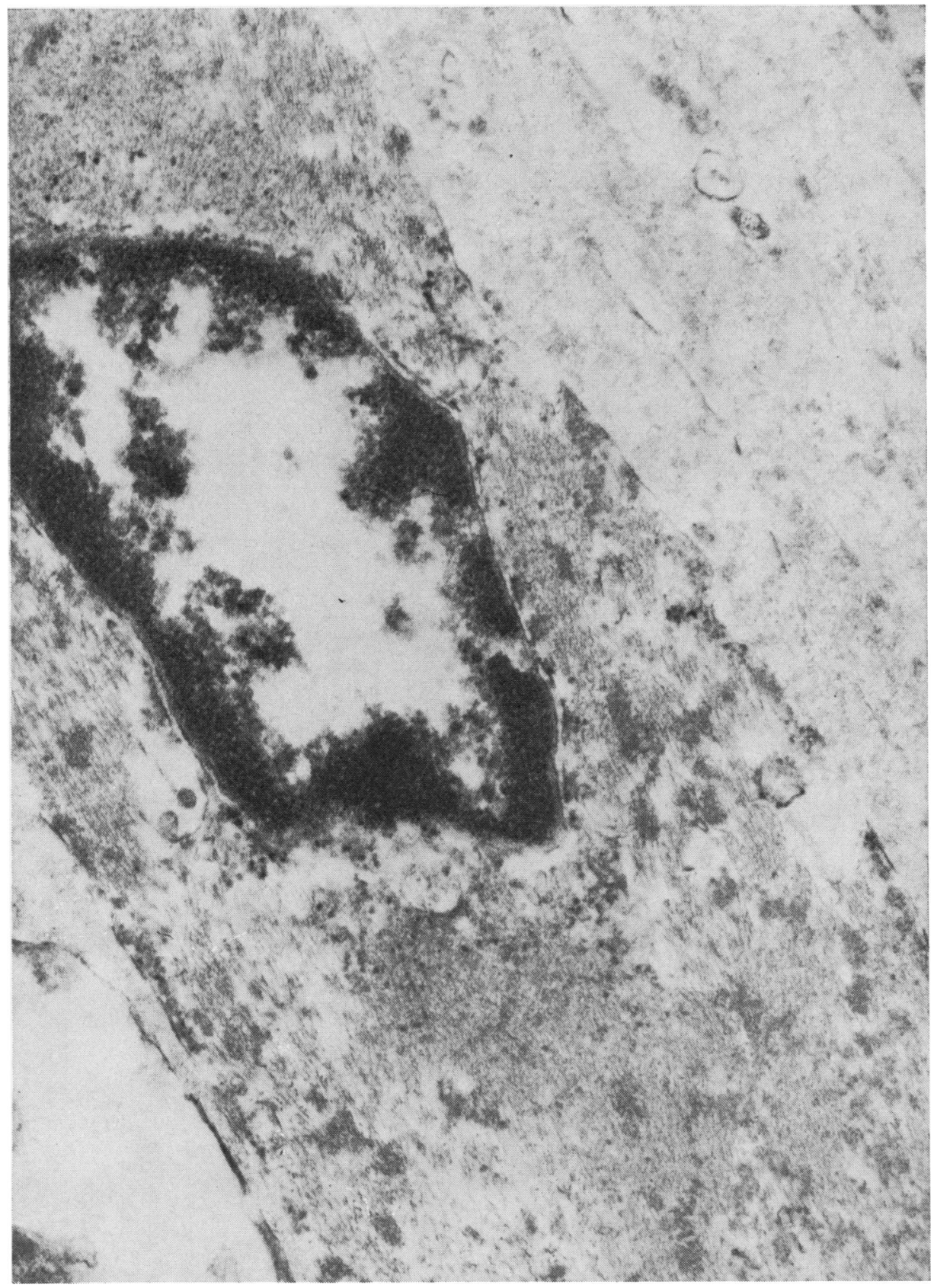

Fig. 8 Higher magnification of 'dark' cell showing masses of cytoplasmic fibrils which resemble neurofilaments. Note absence of granules. $(\times 45000)$ 


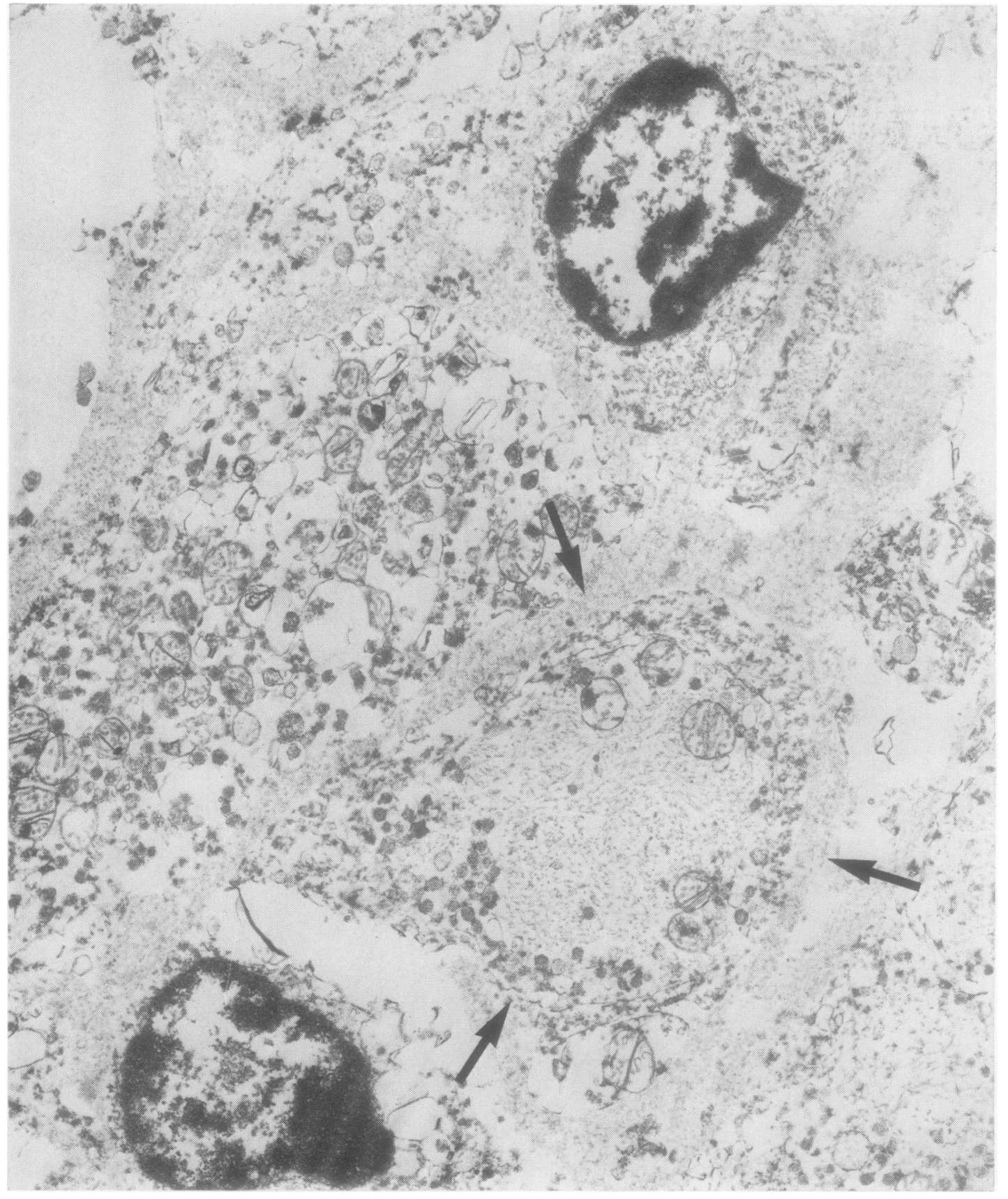

Fig. 9 'Hybrid' cell (arrowed) showing characteristic array of central filaments and peripheral granules. ( $\times 14$ 800) 


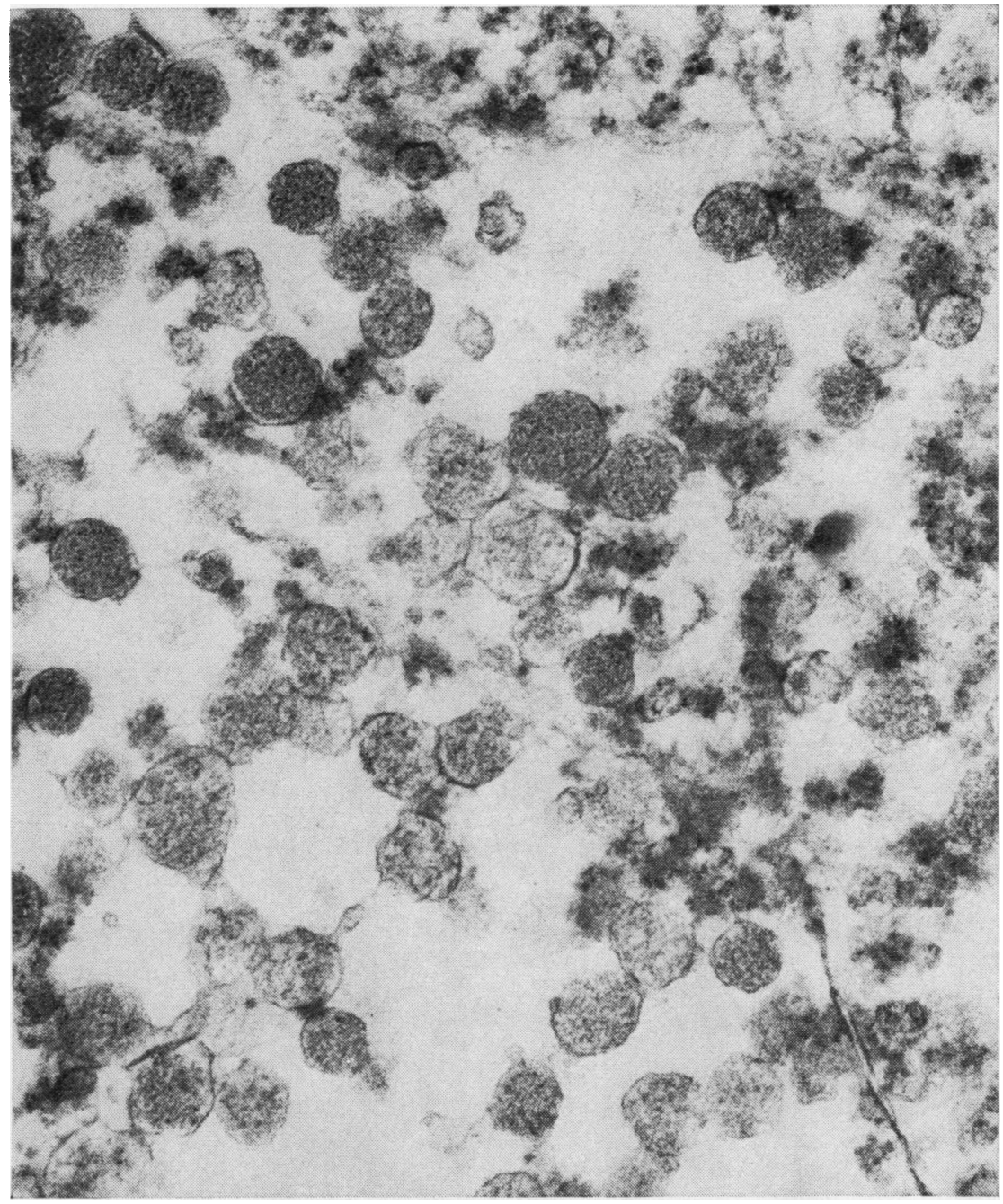

Fig. 10 Electron-dense cytoplasmic granules with peripheral halo and distinct limiting membrane, consistent with catecholamine secretory granules. $(\times 54000)$

cell types above consisted of uniform spherical structures $100-200 \mathrm{~nm}$ in diameter with an electrondense core distinctly separated by a clear halo from a limiting membrane (Fig. 10).

Finally, linear portions of cell bodies which could not be categorised precisely were infrequently seen. These contained secretory granules and prominent membrane-bound, lamellar dense bodies resembling myelin figures (Fig. 11). The latter feature suggests that these are portions of ganglion cells similar to those found in mediastinal ganglioneuromas by Yokoyama et al. (1973). Myelinated nerve fibres were not found.

\section{Discussion}

The occurrence of paraganglia in the normal duo- denum has not been documented. Pearse and Polak (1971) have demonstrated migration of cells from the neural crest to the duodenal mucosa in experimental animals. Paraganglia are also of neurectodermal origin. The probablity that paraganglia occur in the duodenum is heightened by the occurrence of paragangliomas in the duodenum (see above) and its embryological derivative the gallbladder (Miller et al., 1972). In addition, subserosal paraganglia in the gallbladder have been recorded in three instances (Wolff, 1973); and in the contiguous area of the anterior surface of the head of pancreas Cope et al. (1974) have documented the development of a paraganglioma.

Among the 18 cases of duodenal paraganglioneuromas reported to date there is general agreement on the known natural history and morphological 


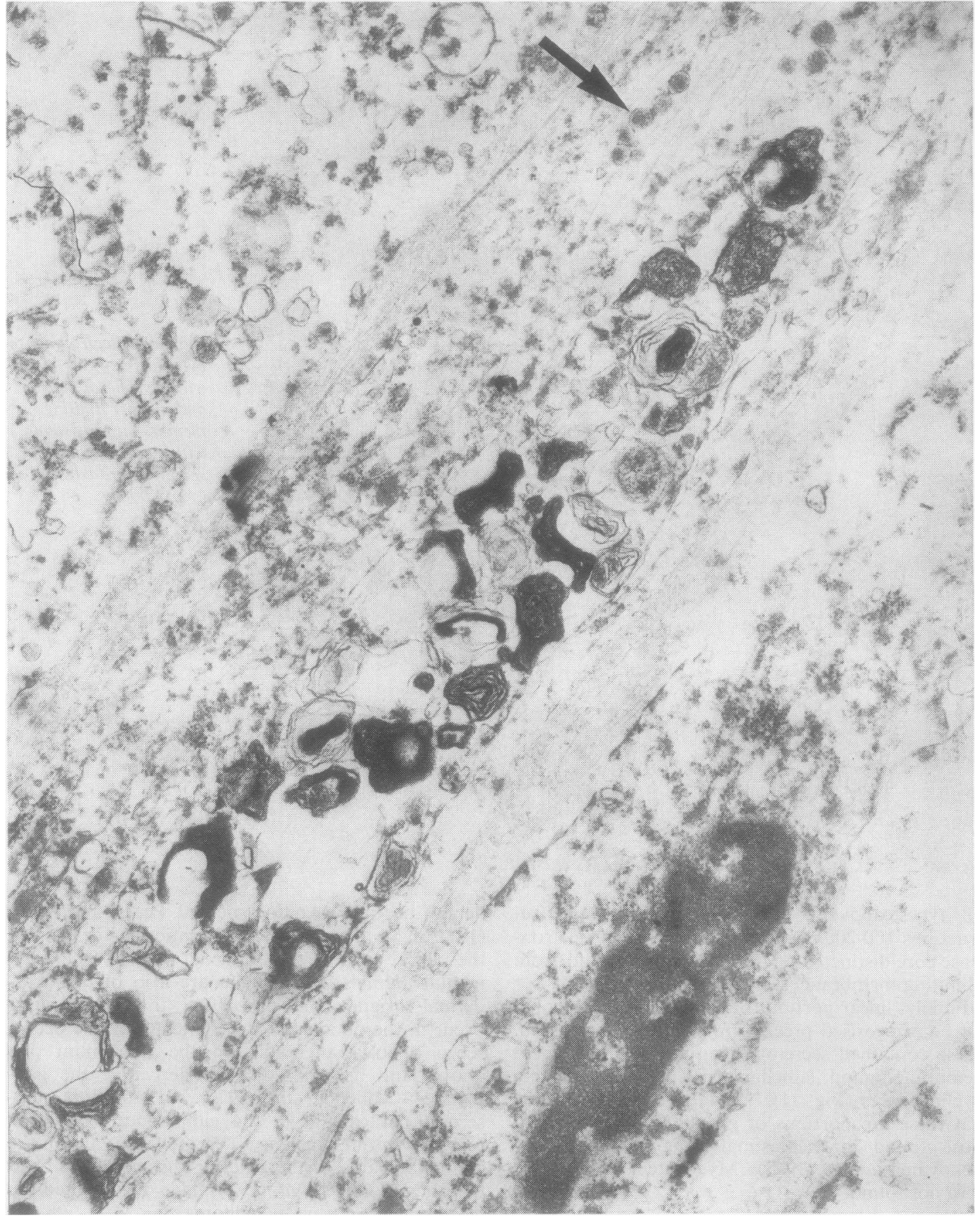

Fig. 11 Cytoplasmic inclusions with prominent lamellated myelin figures and secretory granules (arrowed). 
characteristics of the tumour. The microscopic composition of the tumour, at least on haematoxylin and eosin stained sections, is also generally agreed upon. However, the staining characteristics of the various cell types by silver impregnation methods, the ultrastructural appearances of the tumour cells, and the histogenesis of the tumour are more contentious issues. The duodenal paragangliomas so far recorded in the literature are submucosal, benign, and non-functional. They are typically composed, as in our case, of epithelioid cell nests, areas of spindle cells, and scattered ganglion cells. This cellular composition is similar to that described in paragangliomas at other sites-for example, the carotid body tumour (Willis and Birrell, 1955). Variability in the relative proportions of the constituent cells has been noted as in the predominantly spindle cell tumour in Taylor and Helwig's series (1962) or the tumours described by Lukash et al. (1966) and Qizilbash (1973), which had only a sparse ganglion cell component. The less often described ganglioneuromas of the duodenum may represent predominantly or totally neural variants of this hybrid tumour (Gemer and Feuchtwanger, 1966; Goldman, 1968). This possibility is suggested by the appearance of the tumour described by Dahl et al. (1957) in which the epithelioid cell element occupied an area 'approximately $2 \mathrm{~mm}$ in greatest dimension'.

In our case the epithelioid cell component of the tumour contained cells which were argentaffin, cells which were both argentaffin and argyrophil, and a predominance of cells which exhibited argyrophilia alone. Argentaffin cells have not been described in duodenal paragangliomas before although they have been noted in similar tumours in the gallbladder (Miller et al., 1972) and their presence in the carotid body tumour is well recognised (Costero and Barroso-Moguel, 1961). Most authors agree on the presence of argyrophilic granules in the epithelioid cells of the duodenal paraganglioma.

On electron microscopy we could not detect any difference in secretory granule morphology between the argentaffin or argyrophil cells. The chemical nature of the granules remains speculative, but probably the argentaffin granules contain catecholamine like those seen in ganglioneuromas (Robertson et al., 1964), carotid body tumours (Grimley and Glenner, 1967), phaeochromocytomas, and neuroblastomas (Page and Jacoby, 1964). The argyrophil cells identified in this case and the cases of other authors probably contain polypeptide hormone in common with the argyrophil cells at other sites (Tateishi, 1975). The combination of argentaffinity and argyrophilia in some epithelioid cells suggests that they are more versatile biosynthetically and are capable of elaborating both catecholamines and polypeptide hormones. Identification of secretory granule composition in these tumours, however, awaits the application of specific immuno-staining procedures.

Our descriptive terms 'light' and 'dark' cells refer to the electron microscopic appearance of the granule-containing epithelioid cells and the neurofilament-containing spindle cells respectively. However, these terms have been used by other authors (Kepes and Zacharias, 1971; Qizilbash, 1973; Kermarec et al., 1976) to define cell types that differ from those identified in our case. The terminology requires clarification.

Secretory granules in the tumour discussed here were present in ganglion cells, epithelioid cells, and 'hybrid' cells. Neurofilaments were present in ganglion cells, 'hybrid' cells, and spindle cells. We feel that the hybrid cell, which has been noted by other authors (Kepes and Zacharias, 1971; Qizilbash, 1973) is the key element in this tumour. It is postulated that this represents a stem cell whose evolutionary potential may be expressed by development into either the epithelioid cell containing only secretory granules or the spindle-shaped cell containing only neurofilaments. The finding of some neurofibrils in epithelioid cells or some secretory granules in spindle cells (Kepes and Zacharias, 1971) is consistent with intermediate steps in divergent evolutionary pathways.

We thank Mr F. A. Murray for the photography and Mr J. Dunne for technical assistance with the electron microscopy.

\section{References}

Cope, C., Greenberg, S. H., Vidal, J. J., and Cohen, E. A. (1974). Nonfunctioning nonchromaffin paraganglioma of the pancreas. Archives of Surgery, 109, 440-442.

Costero, I., and Barroso-Moguel, R. (1961). Structure of the carotid body tumor. American Journal of Pathology, 38, 127-141.

Dahl, E. V., Waugh, J. M., and Dahlin, D. C. (1957). Gastrointestinal ganglioneuromas: Brief review with report of a duodenal ganglioneuroma. American Journal of Pathology, 33, 953-965.

Friesen, S. R., Hermreck, A. S., and Mantz, F. A., Jr. (1974). Glucagon, gastrin, and carcinoid tumors of the duodenum, pancreas, and stomach: polypeptide 'Apudomas' of the foregut. American Journal of Surgery, 127, 90-101.

Gemer, M., and Feuchtwanger, M. M. (1966). Ganglioneuroma of the duodenum. Gastroenterology, 51, 689693.

Goldman, R. L. (1968). Ganglioneuroma of the duodenum: relationship to nonchromaffin paraganglioma of the duodenum. American Journal of Surgery, 115, 716-719. 
Grimley, P. M., and Glenner, G. G. (1967). Histology and ultrastructure of carotid body paragangliomas. Cancer, 20, 1473-1488.

Kepes, J. J., and Zacharias, D. L. (1971). Gangliocytic paragangliomas of the duodenum: a report of two cases with light and electron microscopic examination. Cancer, 27, 61-70.

Kermarec, J., Duplay, H., and Lesbros, F. (1976). Paragangliome gangliocytique du duodenum: une observation avec étude ultra-structurale. Archives d'Anatomie et de Cytologie Pathologiques, 24, 261-268.

Lauzon, A., and Cadotte, M. (1972). Paragangliome gangliocytaire du duodénum. L'Union Médicale $d u$ Canada, 101, 1584-1586.

Lukash, W. M., Hyams, V. J., and Nielsen, O. F. (1966). Neurogenic neoplasms of the small bowel: benign nonchromaffin paraganglioma of the duodenum: Report of a case. American Journal of Digestive Diseases, 11, 575579.

Miller, T. A., Weber, T. R., and Appelman, H. D. (1972). Paraganglioma of the gallbladder. Archives of Surgery, 105, 637-639.

Page, L. B., and Jacoby, G. A. (1964). Catecholamine metabolism and storage granules in pheochromocytoma and neuroblastoma. Medicine, 43, 379-386.

Pearse, A. G. E., and Polak, J. M. (1971). Neural crest origin of the endocrine polypeptide (APUD) cells of the gastrointestinal tract and pancreas. Gut, 12, 783788.

Qizilbash, A. H. (1973). Benign paraganglioma of the duodenum: Case report with light and electron microscopic examination and brief review of literature. Archives of Pathology, 96, 276-280.

Robertson, D. M., Hendry, W. S., and Vogel, F. S. (1964). Central ganglioneuroma: a case study using electron microscopy. Journal of Neuropathology and Experimental Neurology, 23, 692-705.

Tateishi, R. (1975). Argentaffin granules in endocrine cells in human duodenal mucosa. Archives of Pathology, 99, 220-224.

Taylor, H. B., and Helwig, E. B. (1962). Benign nonchromaffin paragangliomas of the duodenum. Vir- chows Archiv für pathologische Anatomie und Physiologie und für klinische medizin, 335, 356-366.

Weitzner, S. (1970). Benign nonchromaffin paraganglioma of the duodenum: Report of a case and review of the literature. American Journal of Gastroenterology, 53, 365-369.

Willis, A. G., and Birrell, J. H. W. (1955). The structure of a carotid body tumour. Acta Anatomica, 25, 220-265.

Wolff, M. (1973). Paraganglioma of the gallbladder (Letter). Archives of Surgery, 107, 493.

Yokoyama, M., Okada, K., Tokue, A., and Takayasu, H. (1973). Ultrastructural and biochemical study of benign ganglioneuroma. Virchows Archiv A, Pathologische Anatomie, 361, 195-209.

\section{Addendum}

We have recently seen another such nodule at $\mathcal{W}^{-}$ necropsy in a 69-year-old man. The nodule was in the 9 second part of the duodenum, $1 \mathrm{~cm}$ distal to the ampulla of Vater, submucosal in location, and $1 \mathrm{~cm}$ in diameter. Light microscopy showed epithelioid Zellballen, solid spindle-cell areas, scattered ganglion cells, and progressive branching of a nerve trunk. The relative proportions of these elements within the tumour differed somewhat from the first tumour described in that there was a larger spindle-cell component and a greater number of ganglion cells. Preliminary examination with the electron microscope showed that this tumour was again made up of two cell types-'pale' cells corresponding to the epithelioid cells and containing abundant secretory granules, and 'dark' cells corresponding to the spindle cells and containing neural-type filaments but without secretory granules. No 'hybrid' cells were seen in the preliminary sections. The nature of the secretory granules is being investigated using immunoperoxidase techniques and this will form the basis of a separate study. 